\title{
UK Current Account Sustainability in the Post-Brexit Era: Insights from an Intertemporal Current Account Framework
}

\author{
Vivekanand Jayakumar \\ Economics Department, University of Tampa, Tampa, USA \\ Email: vjayakumar@ut.edu
}

How to cite this paper: Jayakumar, V. (2017) UK Current Account Sustainability in the Post-Brexit Era: Insights from an Intertemporal Current Account Framework. Theoretical Economics Letters, 7, 223-250. https://doi.org/10.4236/tel.2017.72020

Received: January 13, 2017

Accepted: February 25, 2017

Published: February 28, 2017

Copyright $\odot 2017$ by author and Scientific Research Publishing Inc. This work is licensed under the Creative Commons Attribution International License (CC BY 4.0).

http://creativecommons.org/licenses/by/4.0/

\begin{abstract}
British voters decided in a June 2016 referendum that they wanted the UK to leave the European Union (EU). The Brexit referendum result represents a critical turning point for the $\mathrm{UK}$ and the EU alike, and the decision to exit the bloc is bound to have far-reaching consequences. UK's persistent current account deficits and its outsized external assets and external liabilities reflect Britain's deep economic and financial integration with the European Single Market System, and highlight London's central role as Europe's financial capital. Unraveling of the symbiotic relationship between the UK and the EU will profoundly impact Britain's ability to entice foreign investors to fund its current account deficits. Using a rich intertemporal current account framework that incorporates valuation effects, this study examines the potential impact of Brexit on UK's current account sustainability and on UK's net foreign debt position. It argues that a "hard Brexit" outcome would imperil UK's ability to sustain current account deficits. UK's role as a gateway for non-EU states looking to invest inside EU, and the benefits enjoyed by UK-based financial institutions from the European "financial passport" system would both be endangered if UK is shutout of the European Single Market system. UK is bound to become far less attractive to foreign investors in such a scenario, and a rapid and painful current account deficit reduction is probable. On the other hand, the study shows that a "soft Brexit" outcome in conjunction with a sustained and orderly depreciation of the pound would actually improve UK's current account balance and its net foreign debt position.
\end{abstract}

\section{Keywords}

Current Account Sustainability, Net International Investment Position, Intertemporal Current Account Models, Brexit 


\section{Introduction}

In June 2016, British voters rendered a momentous verdict in the so-called Brexit referendum that is likely to have far reaching implications for the United Kingdom (UK) and the European Union (EU). Referendum results indicated that a majority of Britons favored leaving the EU. The unexpected referendum outcome has created a surge of interest in examining the fallout from the Brexit vote (Britain's exit from the EU is simply referred to as Brexit). In the lead up to the referendum vote, the pro-Brexit camp failed to clearly articulate what an exit from the EU might entail from an economic standpoint. Due consideration was not given towards assessing the viability of UK's existing economic model (a finance-dominated, consumer spending driven, and foreign borrowing reliant model) in the post-Brexit era. Instead, the rhetoric from the pro-Brexit camp targeted voters' real and imagined fears over a loss of sovereignty. Brexiteers claimed that a vote to leave the EU would enable UK to escape the regulatory heavy handedness of Brussels-based European institutions and restore its ability to control immigration levels (by abandoning EU's free labor movement rules). The pro-EU remain camp's dire predictions regarding the economic costs of Brexit were often dismissed by opponents as a fear-mongering ploy [1]. Nevertheless, in the referendum aftermath, exploring the economic impact of UK's impending exit from the EU has become a priority for international economists, financial market participants and policymakers.

This study analyzes the potential impact of Brexit on key trade and capital flow interlinkages between the UK and its key trading partners. Specifically, this article addresses questions related to the sustainability of UK's current account deficits (which refers to the ability of UK to easily attract enough foreign capital to finance its persistent current account deficits) in the post-Brexit era. Even prior to the Brexit vote, UK's persistent and growing current account deficits over the past decade had garnered attention amongst international macroeconomists and policymakers [2] [3]. Widening current account deficits (according to UK's Office for National Statistics (ONS), current account deficits of $4.7 \%$ of GDP in 2014 and $4.3 \%$ of GDP in 2015 were the largest deficits that the UK had experienced in the past 60 years) must be matched by equally large capital inflows from abroad. Open economy identities imply that national saving is less than domestic investment in countries experiencing current account deficits, and the saving shortfall must be offset by net foreign borrowing. While the current account balance represents flow-side developments, the international investment position captures stock-side developments. There have been substantial changes in UK's international investment position as well-UK's external assets and external liabilities have both risen significantly over the past two decades. In the aftermath of the Brexit referendum vote, long-term sustainability of UK current account deficits has become a central concern, and any theoretical insights on the issue would be valuable for politicians as well as economists. Brexit is bound to affect the key factors that will determine the ultimate sustainability of UK's current account balances and its net international investment 
position. These factors include UK's attractiveness as an investment destination, the value of the British pound, the returns that foreign investors earn in the UK and the returns that British investors earn abroad, and the relative valuation of domestic asset holdings of foreigners vis-à-vis foreign asset holdings of domestic investors.

Much of the existing economic literature on the sustainability of current account deficits is focused on debates related to the large and persistent US trade deficits-a primary contributor to global imbalances. Global imbalances refer to the emergence of persistent current account surpluses and deficits in key regions of the world economy, especially during the decade that preceded the 2007-09 global financial crisis (see Figure 1). Given the enormity of the American trade and current account deficits in nominal terms and the global significance of the US dollar, it is not surprising that much ink has been spilt analyzing the consequences of the persistent shortfall in US national saving [4] [5] [6]. The surge in domestic oil and natural gas production in the US, slower post-crisis economic growth and the slight pickup in household saving have all contributed to the recent decline in the American current account deficits and alleviated concerns regarding a potentially rapid unwinding of global imbalances. Even as the US

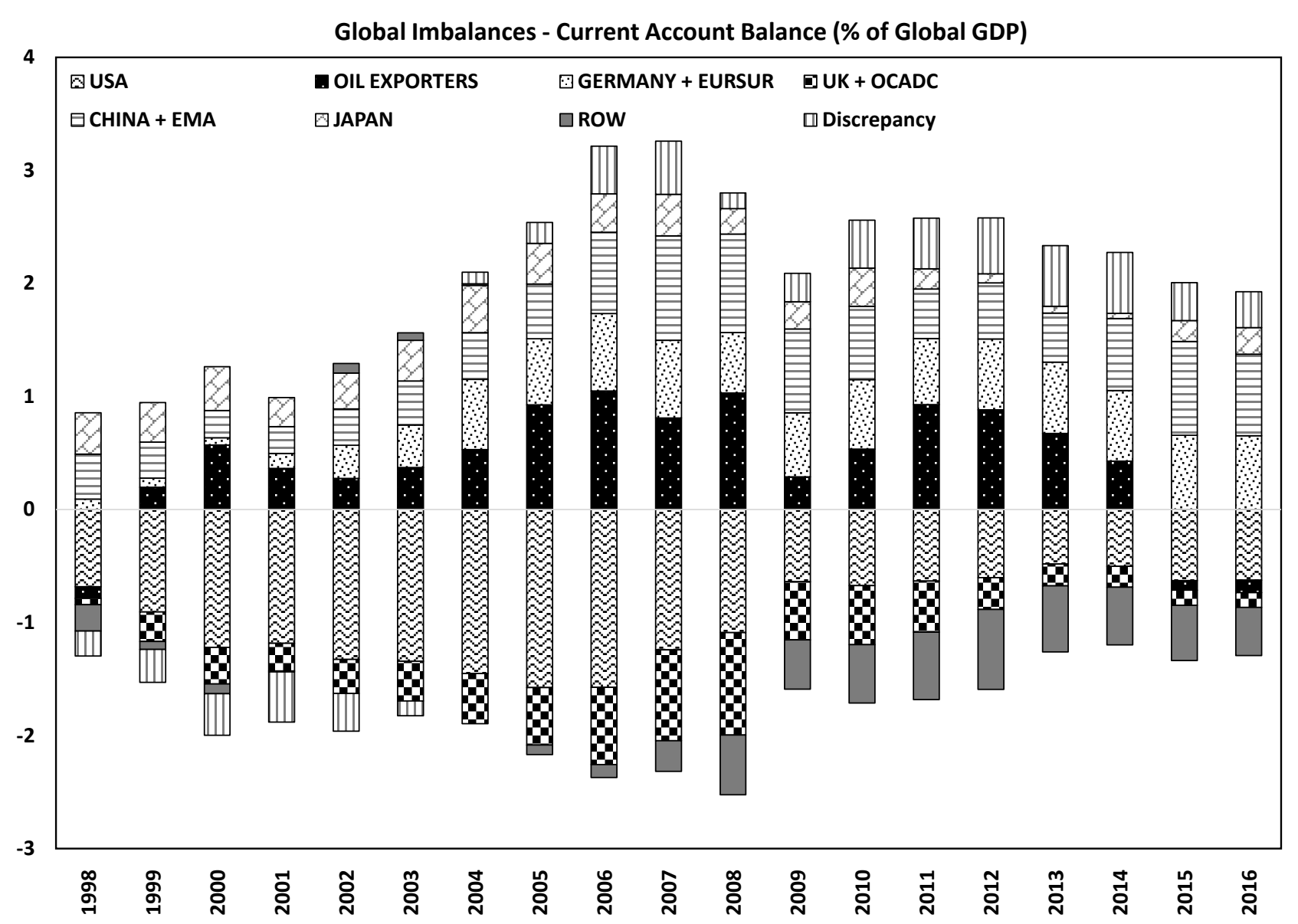

Figure 1. Global Current Account Imbalances (\% of World GDP)-Data Source: IMF World Economic Outlook-October 2016. Note: EMA refers to Emerging Asia; ROW refers to Rest of the World; EURSUR refers to other advanced European surplus economies; and, OCADE refers to other European countries with pre-crisis current account deficits. 
current account deficit fell from its 2006 peak of $\$ 806.73$ billion (equivalent to $5.8 \%$ of US GDP) to $\$ 462.97$ billion (equivalent to $2.6 \%$ of US GDP) in 2015 , the UK current account deficit rose sharply over the past decade-it rose from just around $£ 16.74$ billion (equivalent to $1.2 \%$ of UK GDP) in 2005 to about $£ 80.23$ billion (equivalent to $4.3 \%$ of UK GDP) in 2015. Interestingly, as shown in Figure 1, the large combined current account deficit of UK + OCADE (other European economies with current account deficits in the pre-crisis era) observed during the 2004-2011 period appears to shrink dramatically from 2012 onwards. This trend, however, was entirely due to the dramatic current account improvement achieved, largely under duress (forced austerity resulting from the sovereign debt crisis), by the Eurozone periphery (Portugal, Ireland, Italy, Greece and Spain). Of late, the UK + OCADE balance primarily reflects UK's current account deficit. Figure 2 clearly illustrates the recent worsening of UK current account balances. Currently, as a percentage of GDP, UK has the largest current account deficit amongst major advanced countries.

From a theoretical standpoint, standard intertemporal open-economy macroeconomic models, without any recourse to international political economy considerations and theories of international power dynamics, can only provide an incomplete picture when employed to investigate the persistence of America's

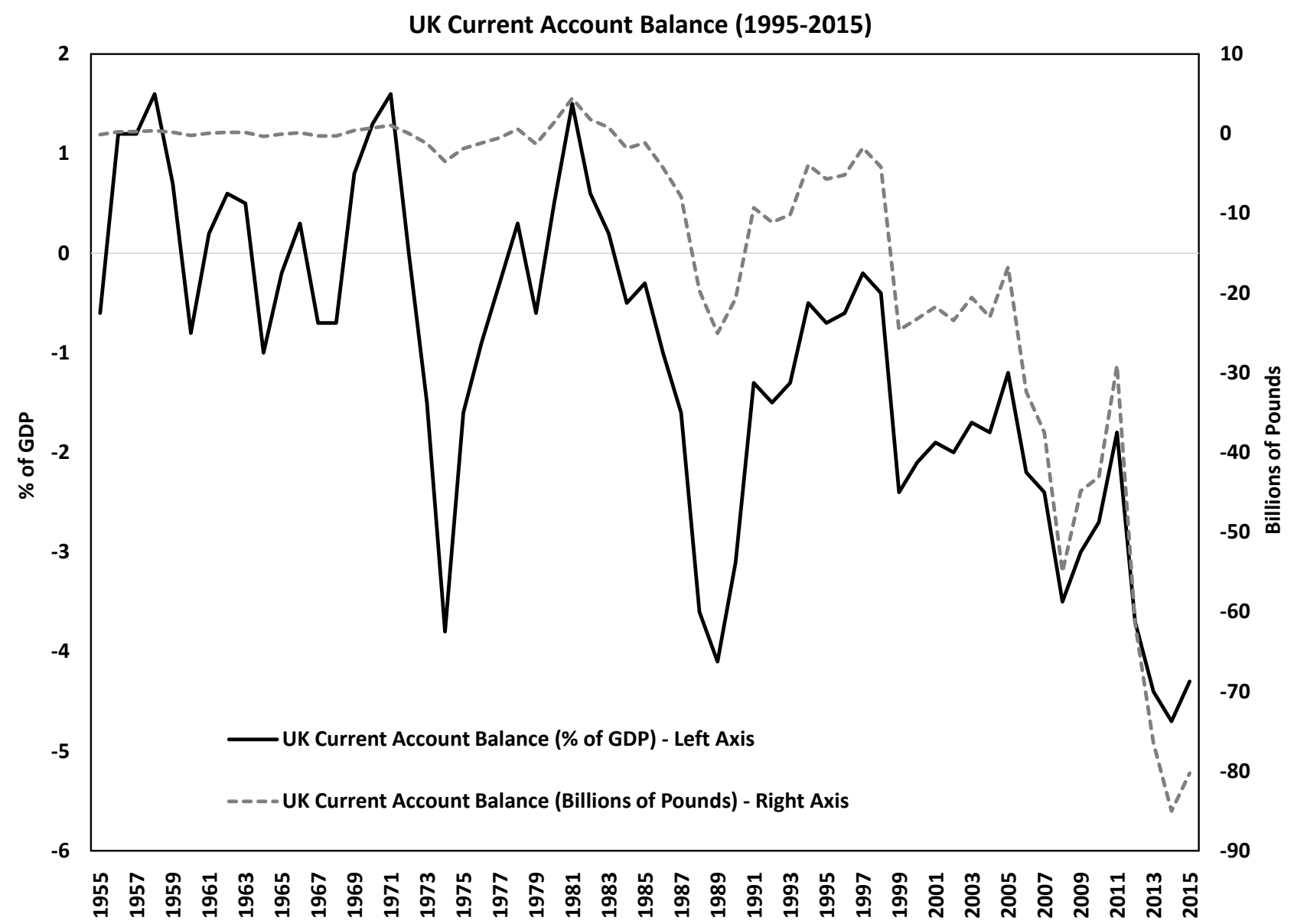

Figure 2. UK current account balance (Data source: UK Office for National Statistics (ONS)). 
trade and current account deficits. US dollar's role as the world's preeminent reserve currency (and the resultant "exorbitant privilege" enjoyed by America; "exorbitant privilege" refers to the rest of the world's readiness to hold large quantities of low-yielding dollar denominated assets) and America's strategic relationship with several key capital providers such as Japan, South Korea, Germany and Saudi Arabia (countries whose security is either formally or informally guaranteed by the US) dramatically complicate any analysis of US current account deficit sustainability [7] [8] [9]. However, in the case of UK (largely unencumbered by complications involving "exorbitant privilege" and security guarantees), intertemporal current account frameworks can provide valuable insights regarding the future direction and long-term sustainability of its current account deficits.

Historically, current account imbalances were analyzed primarily through the trade balance lens (such models were referred to as the elasticity and absorption approaches to the Balance of Payment (BOP))-excessive reliance on imports and the resultant trade deficits were often considered the chief culprits behind persistent current account deficits. Equivalently, it was argued that domestic absorption (absorption refers to the sum of private consumption, government purchases and investment) in excess of domestic production was the underlying driver of current account deficits. The primary focus of these early approaches was on evaluating the impact of exchange rate changes on key trade variables. With the growing prominence of cross-border capital flows, traditional tradeflow centric models gradually became less relevant for examining current account imbalances. Recently, with the shift in emphasis towards forward-looking dynamic decision making and microeconomic foundations based models, the intertemporal approach to current account analysis has become the standard theoretical framework.

An intertemporal current account framework is employed in our analysis of UK's current account sustainability in the post-Brexit era. An important feature of this study is the emphasis placed on the financial components of the current account and on the financial account side of BOP. Unlike traditional approaches, there is also greater stress placed on the exchange rate and asset price change driven valuation effects associated with net international investment position. Two noteworthy factors motivate the approach taken in this study. First, the extraordinary level of financial globalization observed over the past three decades and the concomitant surge in gross international capital flows has created a situation where gross capital flows far exceeds the value of trade and financial account related net capital flows in any given year [10]. Second, London's unique and long-held position as an international financial center has meant that UK's external assets and liabilities are unusually large, and, as such, the impact of net capital flows on net international investment position is often dwarfed by valuation changes associated with external asset and liability positions. The intertemporal framework discussed in this study highlights the role of trade balance, net investment income, and net international investment position in determining 
the sustainability of current account deficits. The framework allows for an explicit consideration of the potential risks posed by large current account deficits-in particular, it highlights the risks associated with large-scale gross capital flows. Reliance on external funding involving both short-term and long-term net private capital inflows exposes a country to the risk of a sudden stop and even a potential reversal in the direction of cross-border flows [10]. Such a shock might induce a disastrous currency depreciation.

The primary focus of this study is a careful evaluation of the impact of Brexit on UK's current account deficits and its net foreign debt position. Our findings can be summarized as follows. If Brexit results in Britain being completely left out of the European Single Market system, and if it causes London to lose its position as Europe's financial capital, then the consequences will be dire. Various forms of capital inflows-direct investment, portfolio investment and bank lending - that currently help finance UK's persistent current deficits will dry up, and a forced reduction in the deficit (which will require a dramatic depreciation of the British pound and a sharp cutback in domestic expenditures) will be inevitable. On the other hand, if successful Brexit negotiations allow Britain to maintain a reasonable amount of access to the European Single Market system and permit UK-based financial institutions to continue to act as the primary intermediaries for EU-wide investments, then the results might turn out to be more positive. Our analysis also suggests that, so far, the swift depreciation of the pound following the referendum has mostly been helpful in regards to UK current account sustainability and net foreign debt position.

The rest of the paper is organized as follows. Section II provides the theoretical basis for undertaking an examination of current account sustainability. Our theoretical approach considers both the standard textbook intertemporal current account model and a richer and more sophisticated intertemporal framework that is especially well-suited for examining UK's current account dynamics. Section III includes a thorough discussion of recent empirical developments related to UK's current account balances and its international investment position. It also includes a detailed analysis, based on the sophisticated intertemporal framework introduced in Section II, of the potential impact of Brexit on the sustainability of UK's current account deficits and on UK's net foreign debt position. Section IV concludes the study with a discussion of the likely outcomes facing Britain under different Brexit scenarios.

\section{Current Account Sustainability-Theoretical Considerations}

The current account $(C A)$ records international flows involving trade in goods and services, international income flows (which consists of compensation of employees and investment income) and current transfers (consisting of unilateral payments-worker remittances, foreign aid, and, in the case of UK, payments to and from the EU). From a BOP accounting standpoint, the current account balance is the sum of the balance on trade in goods and services (referred to 
simply as net exports or the trade balance), the primary income balance (reflecting the net international income flows), and, the secondary income balance (which captures the net unilateral current transfers). Figure 3 illustrates recent developments involving the components of UK's current account balance. A notable highlight is the fundamental shift in UK's primary income balance in recent years. The primary income balance chiefly reflects the income receipts on domestic holdings of foreign assets relative to income payments made on foreign holdings of domestic assets (Note: net employee compensation is generally quite small for the UK-large number of Britons work overseas and many foreigners work in UK and consequently net employee compensation balances out and is quite negligible). For many years, Britons earned more on their overseas asset holding and lending than foreigners did on their UK asset holdings and lending. However, from 2012 onwards, UK's primary income balance has been negative and expectations are that it will continue to linger in negative territory for the foreseeable period. UK's net exports or trade balance has also languished in negative territory for much of the past three decades (trade deficits have been relatively large but stable in the recent past). Given that UK is a rich advanced

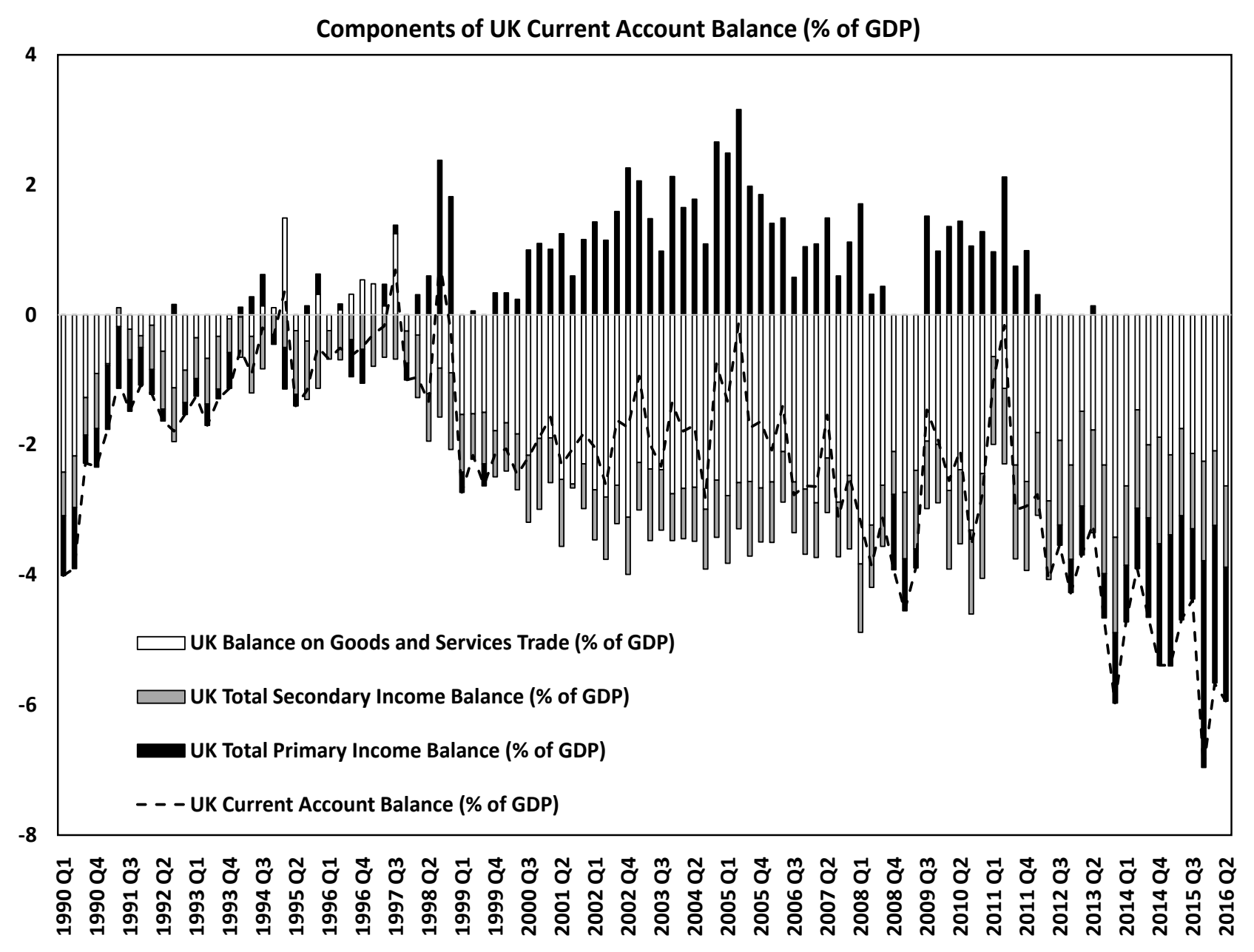

Figure 3. Decomposition of UK current account balance (Data source: Bank of England (BOE) financial stability report-Nov. 2016). 
economy (and as such prone to experiencing net transfers to the rest of the world in the form of worker remittances and foreign aid), secondary income balance has, unsurprisingly, been negative.

Standard open-economy identities provide a good starting point for constructing an intertemporal current account framework. If we denote net exports or trade balance as $N X$, the primary income balance as $P I$, and the secondary income balance as $S I$, then we can define the current account $(C A)$ balance for $\mathrm{UK}$ for any period, $t$, as:

$$
C A_{t}^{U K}=N X_{t}^{U K}+P I_{t}^{U K}+S I_{t}^{U K}
$$

The standard income-expenditure identity is given by Equation (2). Note that $Y_{t}^{U K}$ refers to GDP in period $t, C_{t}^{U K}$ refers to household consumption in period $t, I_{t}^{U K}$ refers to domestic investment in period $t$, and $G_{t}^{U K}$ refers to government purchases in period $t$

$$
Y_{t}^{U K}=C_{t}^{U K}+I_{t}^{U K}+G_{t}^{U K}+N X_{t}^{U K}
$$

If we add primary income balance and secondary income balance, and subtract net taxes (denoted by $T_{t}^{U K}$; it refers to taxes net of transfers) from both sides of the income-expenditure identity, we obtain:

$$
Y_{t}^{U K}+P I_{t}^{U K}+S I_{t}^{U K}-T_{t}^{U K}=C_{t}^{U K}+I_{t}^{U K}+G_{t}^{U K}+N X_{t}^{U K}+P I_{t}^{U K}+S I_{t}^{U K}-T_{t}^{U K}
$$

Combing Equation (1) and Equation (3) and rearranging terms yields:

$$
\left(Y_{t}^{U K}+P I_{t}^{U K}+S I_{t}^{U K}-T_{t}^{U K}-C_{t}^{U K}\right)+\left(T_{t}^{U K}-G_{t}^{U K}\right)=I_{t}^{U K}+C A_{t}^{U K}
$$

The left-hand side of the above equation reflects the sum of private saving $\left(Y_{t}^{U K}+P I_{t}^{U K}+S I_{t}^{U K}-T_{t}^{U K}-C_{t}^{U K}\right)$ and public saving $\left(T_{t}^{U K}-G_{t}^{U K}\right)$, and therefore Equation (4) can be simplified to obtain the important open-economy identity (note: $S_{t}^{U K}$ denotes national saving and is equal to private saving plus public saving):

$$
S_{t}^{U K}=I_{t}^{U K}+C A_{t}^{U K} \Rightarrow S_{t}^{U K}-I_{t}^{U K}=C A_{t}^{U K}
$$

Another crucial open-economy identity arises from the BOP accounting system. The following crucial flow identity (based on the double-entry bookkeeping approach used in BOP accounting system) holds for each period, $t$.

$$
C A_{t}^{U K}+K A_{t}^{U K}+F A_{t}^{U K}=0
$$

The identity states that the sum of the $C A$ and the capital ( $K A)$ and financial account $(F A)$ balance should equal zero. If UK ran a current account deficit $\left(C A_{t}^{U K}<0\right.$ and $\left.S_{t}^{U K}-I_{t}^{U K}<0\right)$, then a financial account surplus $\left(F A_{t}^{U K}>0\right)$ is unavoidable (given that the capital account is typically quite small and can often be ignored). In other words, UK's current account deficit reflects net new acquisition of foreign claims on the UK.

\subsection{Basic Intertemporal Current Account Model}

The standard textbook intertemporal model ([11], pp. 63-66) offers a good starting point for considering long-term sustainability of current account deficits. 
Suppose that secondary income is balanced $(S I=0)$ and that the capital account is equal to zero $(K A=0)$. Let $N I I P_{t}$ represent the net international investment position or the net foreign assets of a country at the start of period $t$. Also, if the ex-post return on net foreign asset is $i_{t}$, then the primary balance can be assumed to equal $i_{t} N I I P_{t}$. If the country has net foreign debt (in which case $\left.N I I P_{t}<0\right)$, then $i_{t}$ is the ex-post payment on net foreign debt. From Equations (1), (2) and (6), we get:

$$
C A_{t}=-F A_{t}=Y_{t}+i_{t} N I I P_{t}-\left(C_{t}+I_{t}+G_{t}\right)
$$

If we ignore valuation effects and exchange rate effects, we obtain the following:

$$
C A_{t}=N I I P_{t+1}-N I I P_{t}
$$

Combining (7) and (8) yields:

$$
N I I P_{t+1}-N I I P_{t}=Y_{t}+i_{t} N I I P_{t}-\left(C_{t}+I_{t}+G_{t}\right)
$$

Equation (9) can be rewritten as:

$$
-\left(1+i_{t}\right) N I I P_{t}=Y_{t}-\left(C_{t}+I_{t}+G_{t}\right)-N I I P_{t+1}
$$

By forward iteration of Equation (10), which involves first rewriting the equation by computing $N I I P_{t+1}$ as a function of $N I I P_{t+2}$, and then repeating the process for $N I I P_{t+2}$, and so on indefinitely, we can restate the above intertemporal condition as follows:

$$
-\left(1+i_{t}\right) N I I P_{t}=\sum_{s=t}^{\infty}\left[\frac{Y_{s}-\left(C_{s}+I_{s}+G_{s}\right)}{(1+i)^{s-t}}\right]-\lim _{s \rightarrow \infty} \frac{N I I P_{s+1}}{(1+i)^{s-t}}
$$

Transversality condition implies that the present value of net foreign asset (or debt) position of an economy in the indefinite future should equal zero $\left(\lim _{s \rightarrow \infty} \frac{N I I P_{s+1}}{(1+i)^{s-t}}=0\right)$. This is often referred to as the no-Ponzi-scheme condition. Also, from Equation (2), we have $Y_{t}-\left(C_{t}+I_{t}+G_{t}\right)=N X_{t}$. Therefore, Equation (11) reduces to:

$$
-\left(1+i_{t}\right) N I I P_{t}=\sum_{s=t}^{\infty}\left[\frac{N X_{s}}{(1+i)^{s-t}}\right]
$$

Per Equation (12), net investment position is equal to the present value of future trade balances. If $N I I P_{t}<0$, then at some point in the future the economy is expected to generate sufficient trade surpluses to pay of the initial foreign debt. Basic version of the intertemporal current account model, like the one described above, downplays the risks associated with current account imbalances. In fact, in a world of forward-looking agents with profit-maximizing firms and utility-maximizing households, current account balances (regardless of their sign or magnitude) would always be consistent with efficient resource allocation ([11], pp. 74).

Figure 4 indicates that the traditionally close link between the trade balance and the current account balance has broken down of late-suggesting that 


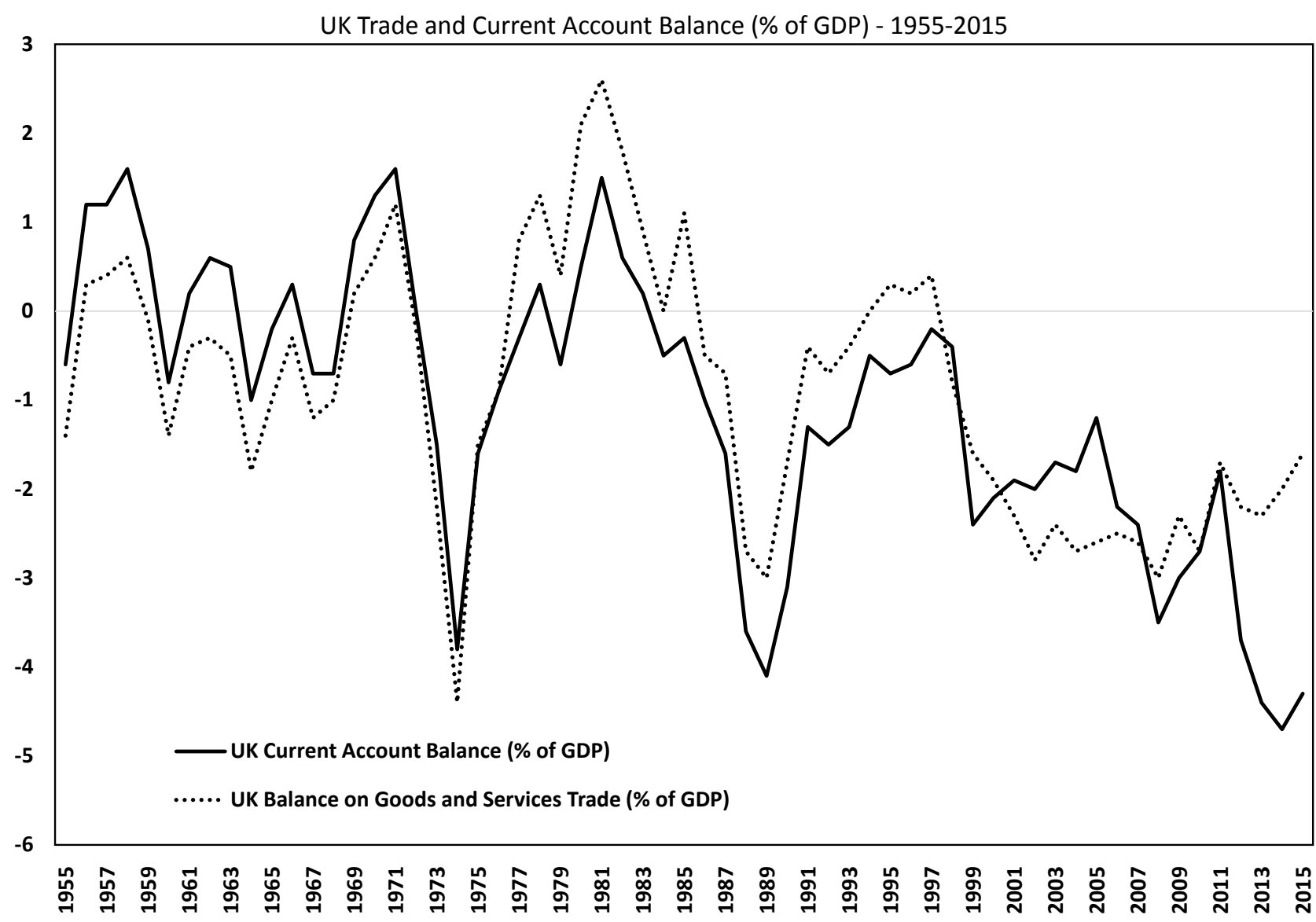

Figure 4. Long-term trends in UK current account balances (Data source: UK Office for National Statistics (ONS)).

primary income balance and to a lesser extent secondary income balance (and the factors affecting those balances) matter as well. Even more significantly, as shown in Figure 5, the net international investment position is increasingly influenced by factors beyond just the current account balance (or the net capital flow represented by the financial account balance). In fact, changes to UK's net international investment position appear to be far less dramatic than would be indicated by the persistent current account deficits (accumulated current account deficit is much larger than the actual net international investment position-suggesting that Equation (8) might be too simplistic a representation of real world developments). Gross two-way financial flows far exceed net flows captured by the current account (or financial account) balance. Clearly, exchange rate effects and valuation effects play a significant role when external asset and debt holdings are substantial [12]. In the following subsection, we introduce a more sophisticated intertemporal approach that stresses financial components in the BOP and explicitly highlights the role of exchange rate changes and asset valuation effects.

\subsection{Current Account Sustainability-A More Sophisticated Intertemporal Approach}

To address the developments highlighted in Figure 4 and Figure 5, and to 
UK Cumulative Current Account Balance and NIIP (Billions of Pounds)

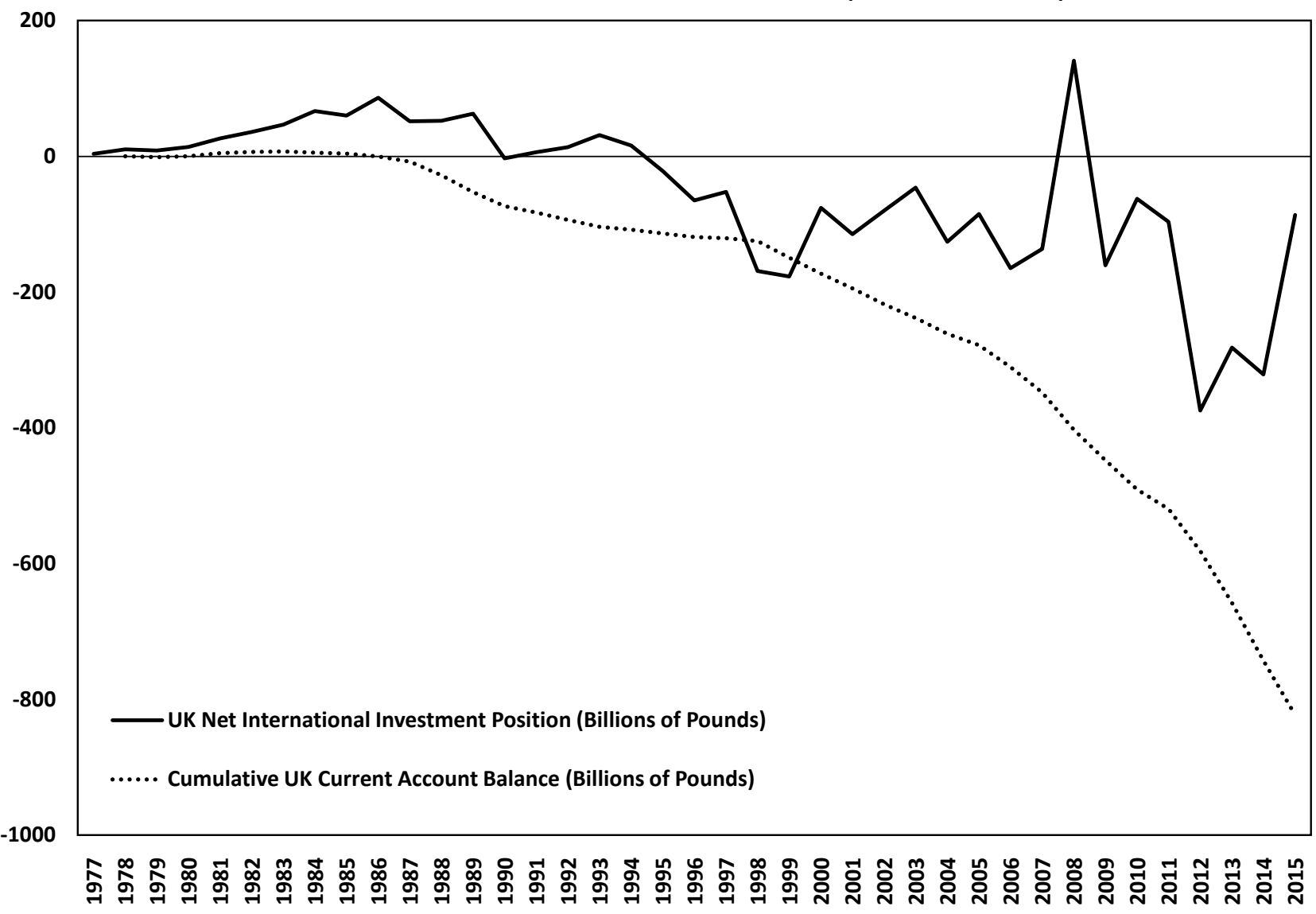

Figure 5. UK's accumulated current account deficit and net international investment position (Data source: UK Office for National Statistics (ONS)).

carefully evaluate the sustainability of UK current account deficits in the postBrexit era, we need a more sophisticated intertemporal framework than the one discussed in the previous subsection. A more realistic framework needs to incorporate the imperfect substitutability of assets-asset characteristics and risk levels differ and assets issued by different countries are not perfect substitutes and consequently it is reasonable to expect differences in asset returns to play a key role. Additionally, a state-of-the-art intertemporal framework should explicitly capture exchange rate and valuation effects ([13], pp. 207-210), which are particularly important for the UK.

Since an advanced economy such as the UK is not likely to suffer from "original sin" (which refers to the inability to issue debt in one's own currency-a common problem amongst emerging markets), we will assume that its debt is denominated in British pounds. Let $\bar{L}_{t}$ represent the domestic currency (British pounds) value of external liabilities. Suppose that $A_{t}$ represents UK's stock of overseas assets (for simplicity, assume overseas asset holdings are denominated in US dollars). Define the nominal exchange rate, $S$, as the number of pounds necessary to purchase a US dollar. The primary income balance (defined here as net investment income) is given by (note that $i_{t-1}^{*}$ is the return earned 
on external asset holdings in period $t$ for overseas credit extended in $t-1$, and, $i_{t-1}$ is the payment made on foreign debt in period $t$, for external liabilities contracted in period $t-1$ ):

$$
P I_{t}=i_{t-1}^{*} A_{t}-i_{t-1}\left(\bar{L}_{t} / S_{t}\right)
$$

If the value of external liabilities (foreign debt stock) measured in dollars is denoted by $L_{t}$ (represents dollar value of foreign debt at the time it was contracted, $t-1$ ), then note that $L_{t}=\bar{L}_{t} / S_{t-1}$. The primary income balance can then be restated as:

$$
P I_{t}=i_{t-1}^{*} A_{t}-i_{t-1}\left(S_{t-1} / S_{t}\right) L_{t}
$$

Adding and subtracting $i_{t-1}\left(S_{t-1} / S_{t}\right) A_{t}$ on the left-hand side of Equation (14) and rearranging terms yields:

$$
P I_{t}=i_{t-1}\left(S_{t-1} / S_{t}\right)\left(A_{t}-L_{t}\right)+\left(i_{t-1}^{*}-i_{t-1}\left(S_{t-1} / S_{t}\right)\right) A_{t}
$$

If we assume that secondary income is exogenously determined $\left(S I_{t}=\overline{S I}_{t}\right)$, and suppose that net exports is a function of the nominal exchange rate (note: $\frac{\partial N X}{\partial S}>0$ ) and $\vec{Z}_{t}$ (a vector representing other factors that can affect the trade balance), then the current account balance can be written as:

$$
C A_{t}=N X_{t}\left(S_{t}, \vec{Z}_{t}\right)+i_{t-1}\left(S_{t-1} / S_{t}\right)\left(A_{t}-L_{t}\right)+\left(i_{t-1}^{*}-i_{t-1}\left(S_{t-1} / S_{t}\right)\right) A_{t}+\overline{S I}_{t}
$$

Simplifying Equation (16) yields:

$$
C A_{t}=N X_{t}\left(S_{t}, \vec{Z}_{t}\right)+i_{t-1}^{*} A_{t}-i_{t-1}\left(S_{t-1} / S_{t}\right) L_{t}+\overline{S I}_{t}
$$

If a country (like the UK) has net foreign debt $\left(A_{t}-L_{t}<0\right)$, and the external liabilities are denominated in its own currency, then the depreciation of the domestic currency will ease the debt burden. The current account balance will improve if the domestic currency depreciates. Besides the potential improvement in the trade balance, depreciation (which implies $S_{t-1} / S_{t}<1$ ) makes the return on external assets appear better than the payments made on external liabilities.

To highlight the significance of gross capital flows, it is helpful to reconsider the link between financial account balance and total asset purchases and sales. If we assume that the capital account balance is negligible, then the BOP identity (see Equation (6)) can be expressed as follows (the current account balance, external asset holdings and external liabilities are measured here in terms of foreign currency-US dollars in this case):

$$
C A_{t}=-F A_{t}=\left(A_{t+1}-\bar{L}_{t+1} / S_{t}\right)-\left(A_{t}-\bar{L}_{t} / S_{t}\right)
$$

As previously noted, $L_{t}$ is the dollar value of external liabilities in the period the debt was contracted. That is $L_{t}=\bar{L}_{t} / S_{t-1} \Rightarrow S_{t-1} L_{t}=\bar{L}_{t}$. Also, $S_{t} L_{t+1}=\bar{L}_{t+1}$. Equation (18) can therefore be restated as:

$$
C A_{t}=\left(A_{t+1}-L_{t+1}\right)-\left(A_{t}-S_{t-1} L_{t} / S_{t}\right)
$$

Adding and subtracting $L_{t}$ to the left-hand side of (19), we get:

$$
C A_{t}=\left(A_{t+1}-L_{t+1}\right)-\left(A_{t}-L_{t}\right)-\left(1-S_{t-1} / S_{t}\right) L_{t}
$$


If we note that $N I I P_{t+1}-N I I P_{t}=\left(A_{t+1}-L_{t+1}\right)-\left(A_{t}-L_{t}\right)$, then Equation (20) can be rewritten as:

$$
N I I P_{t+1}-N I I P_{t}=C A_{t}+\left(1-S_{t-1} / S_{t}\right) L_{t}
$$

Generalizing, change in NIIP between periods $t+n$ and $t$ is given by:

$$
N I I P_{t+n}-N I I P_{t}=\sum_{i=0}^{n-1} C A_{t+i}+\sum_{i=0}^{n-1}\left(1-S_{t-1+i} / S_{t+i}\right) L_{t+i}
$$

Per Equation (22), in addition to current account balance changes, valuation effects resulting from exchange rate changes also affects a country's net international investment position. Specifically, a depreciation of the domestic currency $\left(S_{t-1} / S_{t}<1\right)$-decline in the value of the British pound in our case-reduces the value of net foreign debt measured in US dollars. The rationale is obvious but of great consequence-a country whose external liabilities are denominated in its own currency obtains a beneficial reduction in net foreign debt when its currency depreciates. Also, note that combining Equations (17) and (21) yields, after some algebraic manipulation, the following useful relationship:

$$
N I I P_{t+1}=N X_{t}\left(S_{t}, \vec{Z}_{t}\right)+\left(1+i_{t-1}^{*}\right) N I I P_{t}+\left(1+i_{t-1}^{*}\right)\left(1-\left(\frac{1+i_{t-1}}{1+i_{t-1}^{*}}\right) \frac{S_{t-1}}{S_{t}}\right) L_{t}+\overline{S I}_{t}
$$

From Equation (23), we know that a country facing net foreign debt $\left(\right.$ NIIP $\left._{t}<0\right)$ will see a decline in its degree of foreign indebtedness position if returns on external asset holdings exceed returns on external liabilities, and if the domestic currency depreciates.

While the above equations explicitly highlight the role of exchange rate related valuation effects on a country's current account sustainability and on its net international investment position, we can generalize even further by observing that additional valuation effects can arise as result of changes in the prices of both domestic and foreign asset holdings. A generalized version of Equation (22) can be stated as follows (where $X_{t}$ represents the net capital gains (or losses) in period $t$ resulting from variations in both exchange rates and underlying domestic and foreign asset prices):

$$
N I I P_{t+n}-N I I P_{t}=\sum_{i=0}^{n-1} C A_{t+i}+\sum_{i=0}^{n-1} X_{t+i}
$$

The insights gleaned from the above discussion make it clear that simple trade-flow centric approaches will not suffice. Developments involving the trade balance alone cannot provide clarity regarding the long-term sustainability of trade and current account deficits. Additional factors related to gross capital flows and currency values need to be incorporated in any analysis of current account sustainability. To summarize, the intertemporal current account frameworks discussed in this section indicate that primary income balance (reflecting, primarily, the net investment income), and, valuation effects arising from changes in exchange rates and in the prices of foreign assets held by domestic residents and in the prices of domestic assets held by foreigners need to be accounted for in order to obtain a full understanding of a country's net investment position and its ability to sustain current account deficits. 


\section{UK's Current Account Sustainability-Evaluation of Potential Post-Brexit Scenarios}

This section first provides a careful examination of recent developments involving the components of UK current account. It also highlights the primary drivers of the recent deterioration in UK current account deficits. A discussion of the underlying trends in UK's net international investment position is also included. Following which an assessment of the potential impact of Brexit on the sustainability of UK current account deficit is provided. Potential changes to UK's net investment position in the aftermath of Brexit are also considered.

\subsection{UK Current Account Sustainability—Recent Trends}

As previously noted, UK has experienced persistent current account deficits over the past three decades. Recent developments (see Figure 3 and Figure 4) suggest that to fully grasp the factors responsible for the recent deterioration of UK's current account balances, it is necessary to consider changes in the primary income balance. Placing emphasis solely on trade balance will no longer suffice. As shown in Figure 6, previous episodes (1970-1974 and 1985-1989) of deteriorating current account balances were chiefly caused by a worsening of the trade balance. However, the worsening of the current account deficit since 2010 has

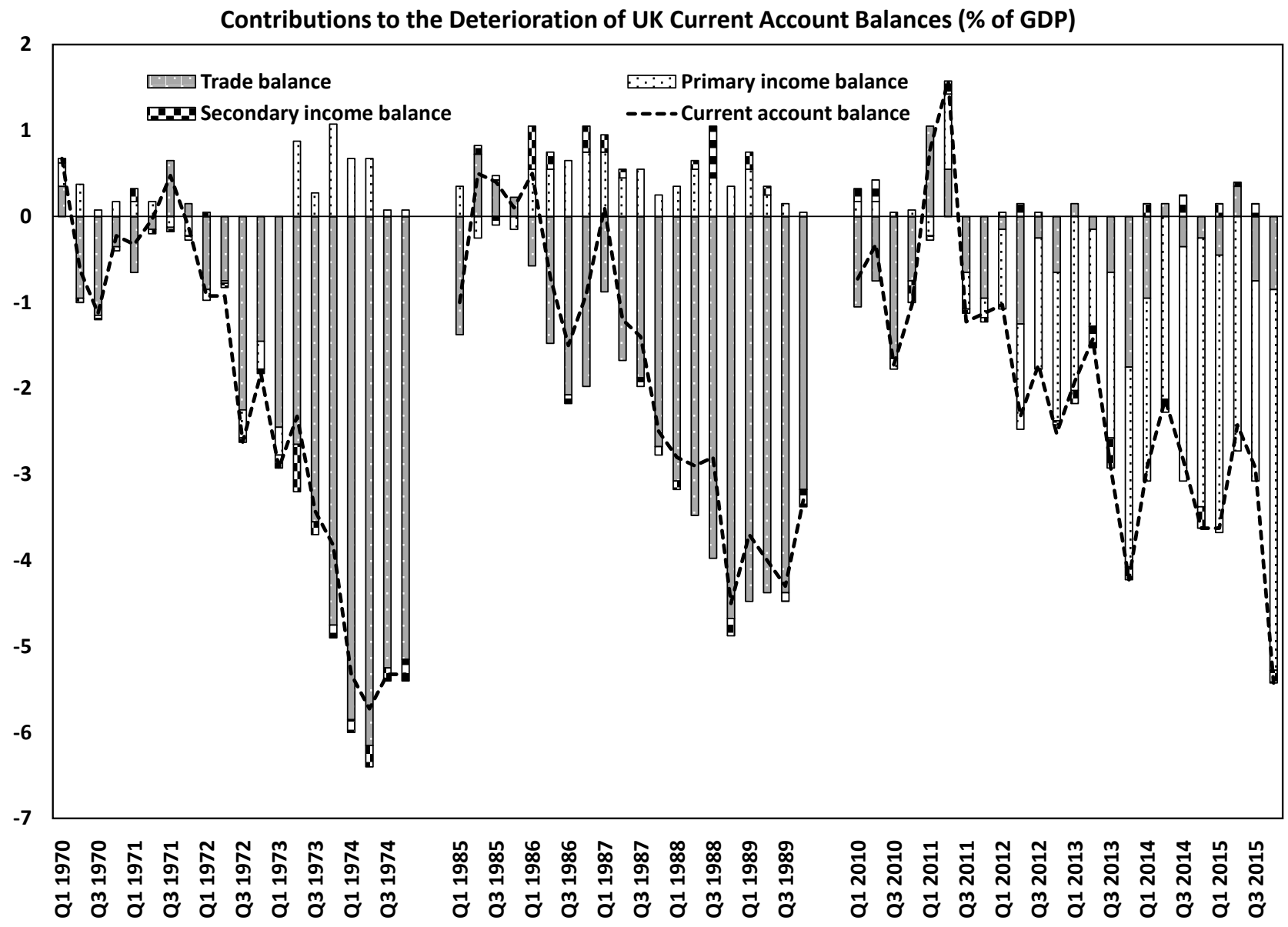

Figure 6. Contribution to deterioration of UK current account balances (Data source: UK Office for National Statistics (ONS)). 
largely been driven by the decline in the primary income balance (in fact, primary income balances have turned negative of late). Negative net investment income (underlying cause of negative primary income balances) implies that the UK residents are earning less on their foreign assets and lending than foreigners are earning on their British assets and lending. On the trade balance front, UK has been experiencing a structural trade deficit of around $2 \%$, which appears to largely be driven by the sizable trade deficit with EU trading partners. Figure 7 indicates the trade balance relationship between the UK and its key trading partners. UK typically runs a trade surplus in services but that is more than offset by the sizable trade deficit in goods (mainly with the rest of EU and China). If these trends persist, based on Equations (17) and (23), we can expect UK to continue to experience sizable current account deficits.

To fund the persistent current account deficit, UK residents have sold domestic assets and increased their external liabilities (implying a financial account surplus). As Bank of England Governor Mark Carney noted in early 2016 during an appearance in front of the British Members of Parliament (part of a Treasury Select Committee), the UK relies on the "kindness of strangers" to finance its current account deficit. Figure 8 illustrates recent trends in UK financial account balance (note that from Equation (6), we get $C A_{t}^{U K}+K A_{t}^{U K}=-F A_{t}^{U K}$ ).

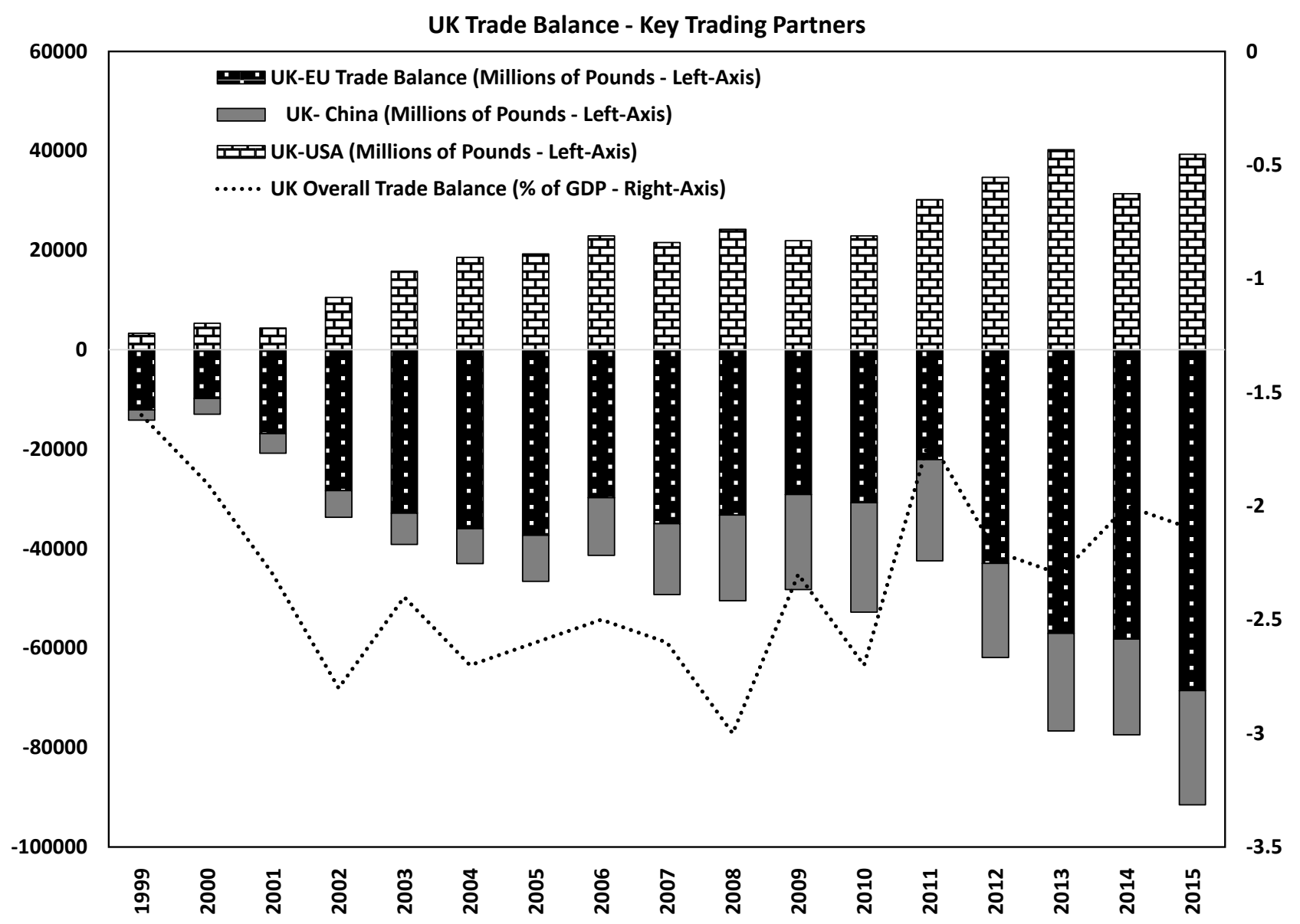

Figure 7. UK's trade balance with key trading partners (Data Source: UK Office for National Statistics (ONS)). 


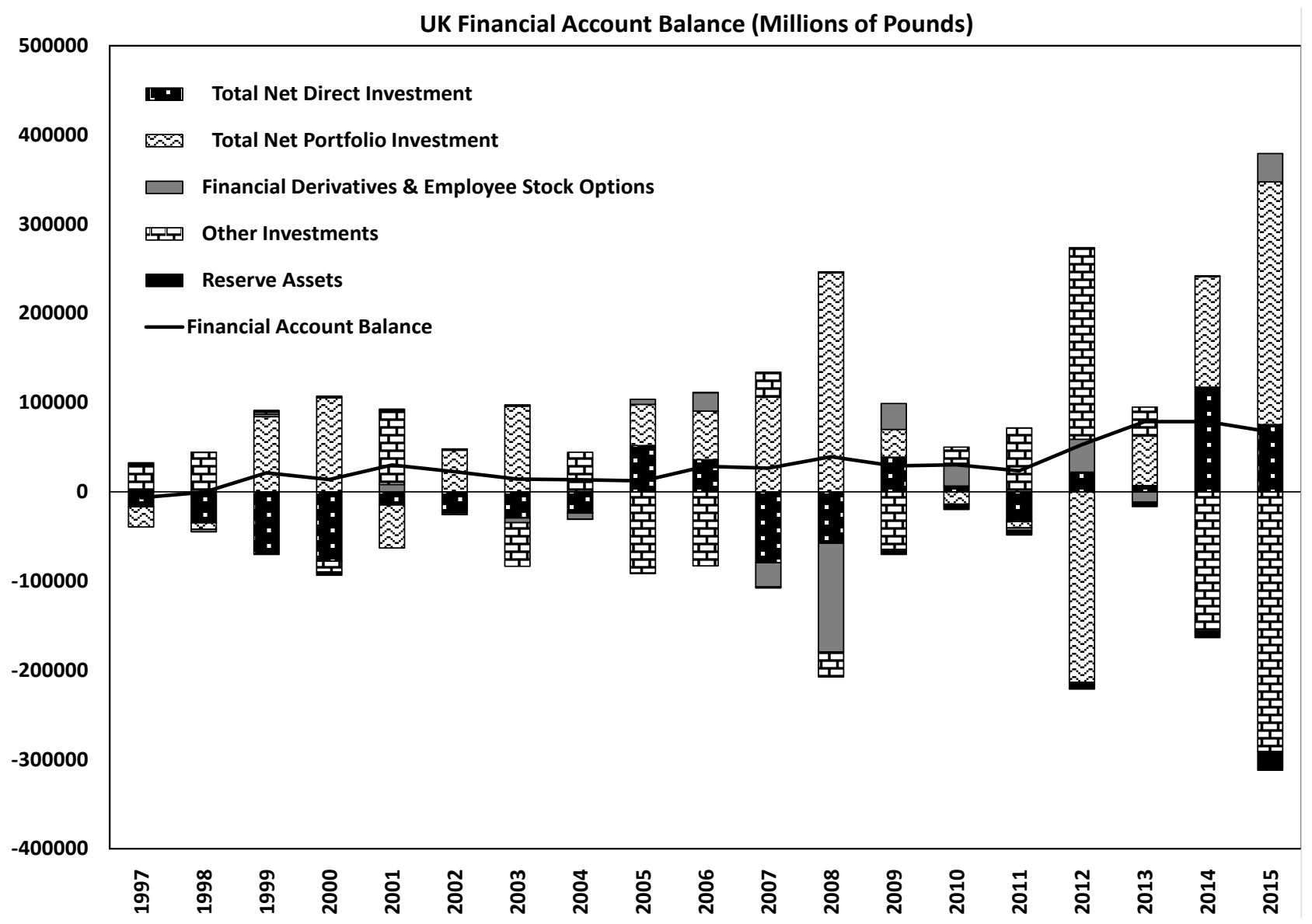

Figure 8. UK's financial account balance (Data source: UK Office for National Statistics (ONS)).

Attracting foreign direct investment (FDI), foreign portfolio investment (FPI) and other forms of foreign investment is the primary way in which UK funds its current account balance.

While the above discussion focuses on flow-side developments involving UK's Balance of Payments, it is also worth considering stock-side changes involving UK's external assets and liabilities, and its net international investment position [14]. From the intertemporal approaches discussed in the previous section (see Equations (22)-(24)), it should be clear that any analysis of current account deficit sustainability requires an examination of the net international investment position. Figure 9 highlights recent developments involving UK external assets (foreign assets owned by UK residents) and UK external liabilities (UK assets owned by foreign residents). External asset holdings and external liabilities both have reached extraordinary levels in recent years-between 4 to 7 times the size of UK's nominal GDP. The enormous size of the UK's external assets and external liabilities is due to increasing financialization of the UK economy, and, more significantly, due to London's role as a major international financial center. With both external assets and external liabilities often hovering between $400 \%$ $700 \%$ of GDP, valuation effects (resulting from asset price changes and exchange rate changes) are bound to play an outsized role in determining UK's net international investment position. 


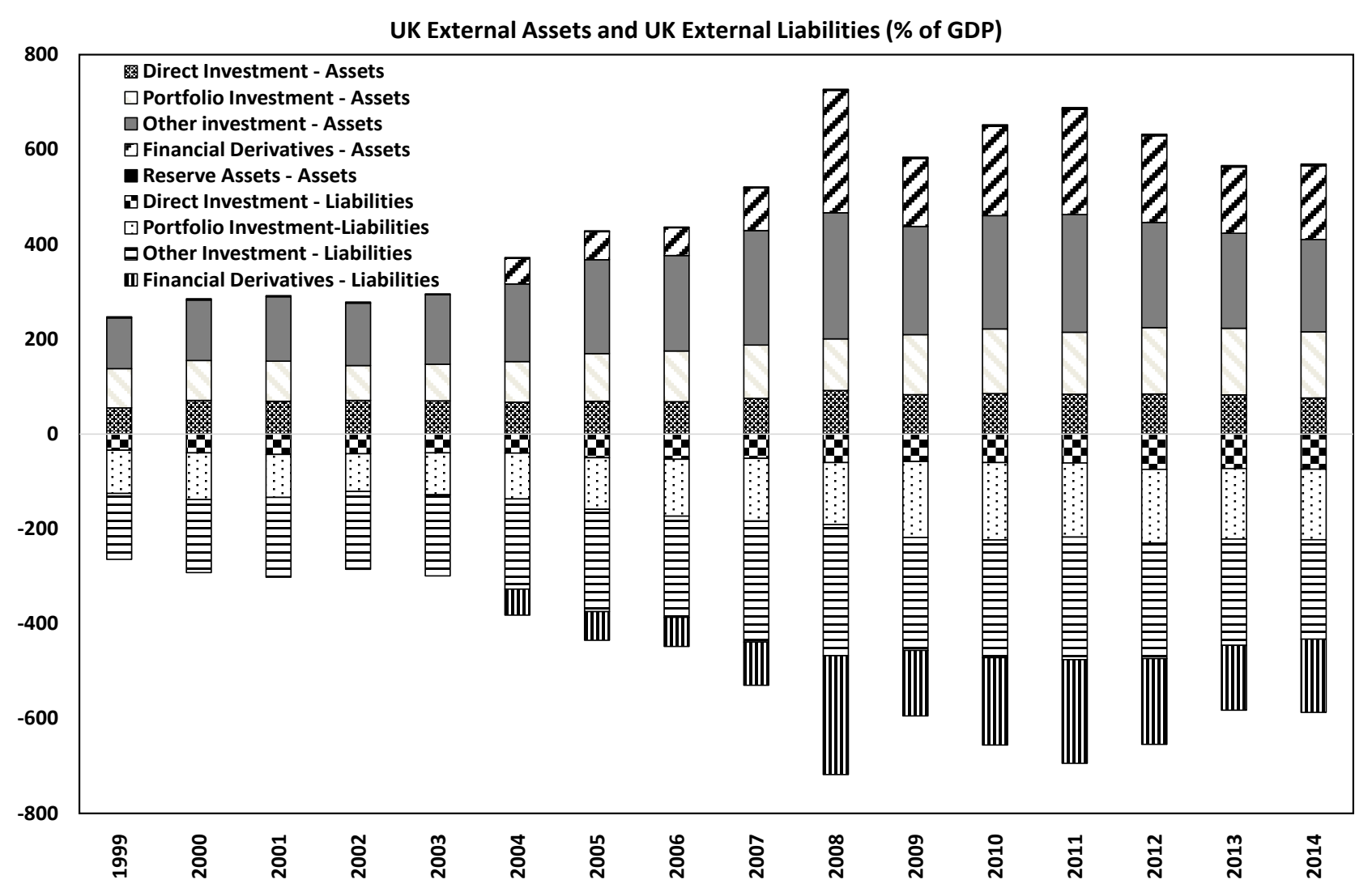

Figure 9. UK's international investment position (Data source: UK Office for National Statistics (ONS)).

As previously noted (see Figure 5), the accumulated current account deficits are far larger than the actual net foreign debt position of UK. From Equation (22) and Equation (24), it is clear that valuation effects truly matter when evaluating the extent of UK's foreign indebtedness. Figure 10 provides a helpful breakdown of the impact of net financial flows vis-à-vis valuation changes on UK's net international investment position (changes involving financial derivatives and reserve assets are not shown). As suggested by the intertemporal framework, a currency depreciation reduces net foreign debt-for instance, in 2008, following a nearly $28 \%$ devaluation of the British pound against the US dollar, UK's net international investment position experienced a significant positive effect from currency changes.

Evidence provided in this subsection indicates that in the recent past (especially since 2011) UK current account deficits have worsened. A structural trade deficit (primarily with other EU member states) has been a steady contributor to the current account deficit. However, more recently, the shift from a positive primary income balance to a negative primary income balance has been the chief contributor to the deterioration in UK current account balances. Interestingly, despite the persistence of current account deficits, there has only been a modest change in UK's net international investment position. Revaluation of UK's massive external assets and external liabilities (primarily due to the depreciation of the British pound and to a lesser extent due to asset price changes) played a crucial in limiting the deterioration of Britain's net foreign debt position. 
UK NIIP - Net Financial Flows and Valuation Effects (Billions of Pounds)

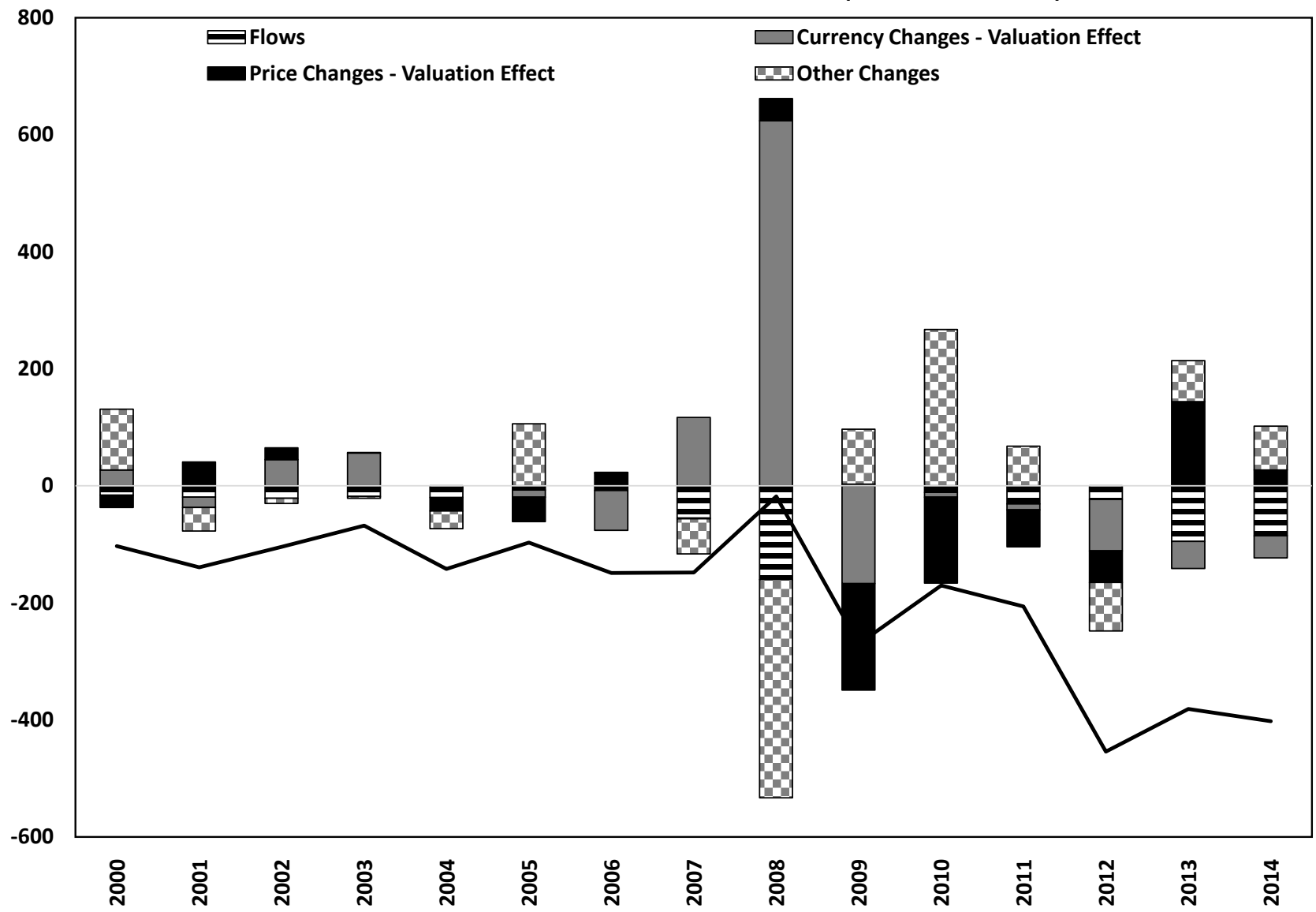

Figure 10. Factors contributing to changes in UK's net investment position (Data Source: UK Office for National Statistics (ONS)).

\subsection{UK Current Account Sustainability—Potential Impact of Brexit}

The previous subsection provided relevant information on recent trends associated with UK current account balances and its net foreign debt position. Before examining the potential impact of Brexit on the future direction and sustainability of UK current accounts, it is worth noting that persistent current account deficits might pose a risk even to advanced economies. In theory, in a world characterized by "complete and perfect" capital markets, current account balances may just reflect ex-ante decisions made by countries to optimally share and diversify their idiosyncratic, country-specific risks [12]. However, in the modern era of financial globalization, large-scale gross capital flows may be motivated by the need to take advantage of regulatory/tax arbitrage opportunities and of other forms of distorted incentives rather than by the desire for optimal wealth transfers allocations via (theoretically) efficient international financial markets. Consequently, in the real world, countries can buildup sizable currency and maturity mismatches that increase their underlying risk exposure [12]. As noted in the previous subsection, given the extraordinary size of UK external asset holdings and UK external liabilities, it might be foolhardy to assume that persistent current account deficits and sizable fluctuations in net international 
investment position do not matter. Consequently, any analysis of the possible impact of Brexit on UK's current account and net foreign debt positions needs to consider underlying changes in actual or perceived risk levels.

In the leadup to the Brexit referendum, the UK Treasury released a report examining the potential short-term economic impact of a British exit from the EU [15]. The UK Treasury report suggested three possible channels for examining the potential economic impact of Brexit: (1) the transition effect-the impact arising from the expectation that the UK economy would become relatively less open to trade and investment following the loss of full EU membership; (2) the uncertainty effect-the inevitable spike in uncertainty following the referendum vote and the continuing ambiguities regarding the course of future policy regimes; and, (3) the financial conditions effect-heightened financial volatility caused by the perception that the UK may become a less appealing and riskier place to invest. These three channels are also relevant for evaluating the impact of Brexit on UK's current account sustainability and net foreign debt.

Following the June 2016 Brexit referendum result, the British government is expected to invoke Article 50 of the Lisbon Treaty (sometime in 2017) to formally declare its intention to exit the EU. This will initiate a two-year negotiation period during which the status of UK's future relationship with the EU will be determined. Obviously, this is going to be a period fraught with uncertainty, and the potential for significant economic, financial and political turbulence exists. It is reasonable to assume that UK's access to the European Single Market will be curtailed following the completion of formal exit negotiations. Consequently, far-reaching post-Brexit changes to the UK economy (especially, for its dominant financial sector) is to be expected.

London's role as the financial capital of Europe and UK's role as a gateway or entry point for non-EU capital looking to enter the single market are predicated to a large extent on Britain's EU membership. As a member of the EU, UK enjoys full access to the European Single Market system-this arrangement guarantees free movement of capital, labor, goods and services within the broader European Economic Area (comprising of 28 EU member states, Norway, Liechtenstein, and Iceland). Importantly, EU membership confers the benefits of the so-called European "financial passport" on UK-based institutions. Under the "financial passport" system, "a financial institution licensed in the UK (the home country) is legally entitled to provide services in another member state (the host country) without needing any further regulatory authorization" ([16], pp. 365). UK's banking system is one of the biggest in the world and is also one of the most internationalized: the banking sector, whose size was around $100 \%$ of GDP in 1975 , had grown to about $450 \%$ of GDP in 2013; also, foreign bank branches accounted for around $30 \%$ of total UK resident banking assets-the highest figure for any major economy [17]. From a current account sustainability perspective, it is worth emphasizing that any loss of UK's privileged access to EU financial markets will materially affect London's position as the leading intermediary of non-EU FDI, FPI and other forms of investment into the EU [16]. 
If Brexit were to undermine UK's status as a gateway into the European Single Market system, then we cannot expect the sizable FDI and FPI flows into UK from both EU and non-EU states to continue as before [18]. As indicated in our earlier discussion (see previous subsection), the ability to attract foreign capital is central to UK's ability to sustain large current account deficits. If the transition effect and uncertainty effect associated with Brexit reduces UK's attractiveness as an investment destination and raises its risk premium, then Britain will face pressure to curtail its current account deficits.

As shown in Figure 11, a sole bright spot in UK's current account balance is the persistent trade surplus in services (EU currently accounts for nearly threequarters of UK's trade surplus in services). To a considerable extent, the trade surplus in services is dependent on London's position as a leading international financial center. Financial services, insurance and pension services, along with associated legal, accounting and management services contribute significantly to sizable UK trade surplus in services [16]. If Brexit were to impinge on London's role as a global financial and banking center, then maintaining substantial trade surplus in services will be difficult, which, in turn, will adversely affect the sustainability of large current account deficits. It is worth noting that Brexit's impact on the trade front may not be limited to just the service sectors. There is a distinct possibility that exit from EU will raise both goods and services trading costs for UK and reduce overall trade in the near to medium run [19].

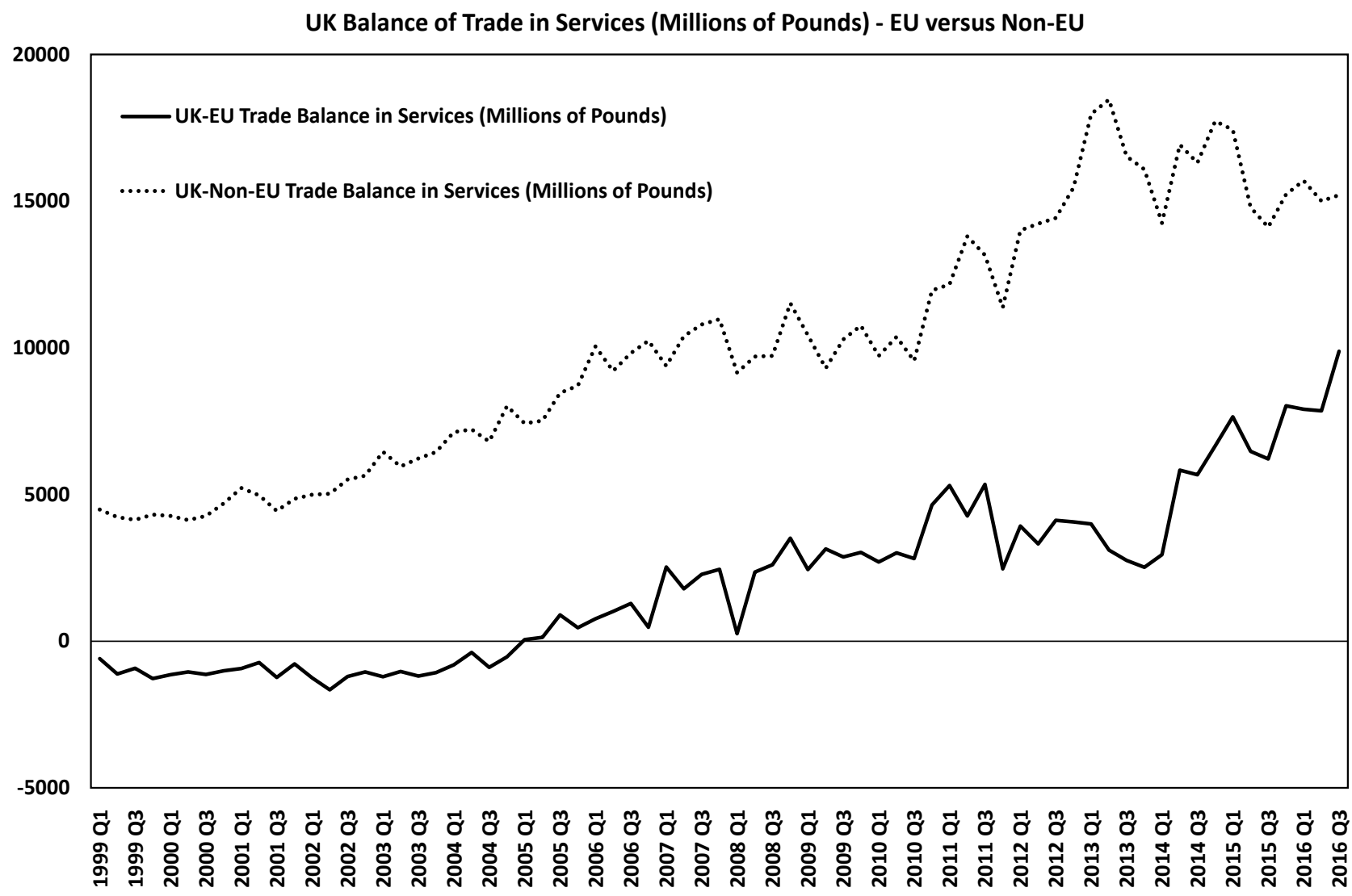

Figure 11. UK trade balance in services (Data source: UK Office for National Statistics (ONS)). 
The most dramatic short-term reaction to the Brexit referendum result was observed in the foreign exchange market-the British pound tumbled quickly against the US dollar and other major currencies. The US dollar-British pound exchange rate tumbled to thirty year lows and the effective exchange rate index also hit multi-decade lows (Figure 12). Heightened risk of financial volatility, in combination with increased uncertainty and concerns about the continued openness of UK to trade and investment, have adversely affected the value of the British currency. The intertemporal framework discussed in the previous section (see Equation (22) and Equation (23)) suggests that a currency depreciation/ devaluation has favorable effects on current deficits and on net foreign debt. Valuation effect is especially significant, if, as in the case of UK, external liabilities are denominated in the domestic currency (British pound). In fact, a recent Bank of England (BOE) study noted: "For the UK, an increase in domestic risk leads to positive valuation effects on its international portfolio that help share the costs of heightened domestic uncertainty internationally in a meaningful way. However, an increase in global risk generates negative valuation and return effects due to the composition of the UK's international portfolio" ([20], p. 24). The rationale is straightforward-when UK risks rise relative to global risks, the pound tumbles and this leads to a positive effect on valuation of UK's international portfolio (currency composition of UK's external assets and external liabilities

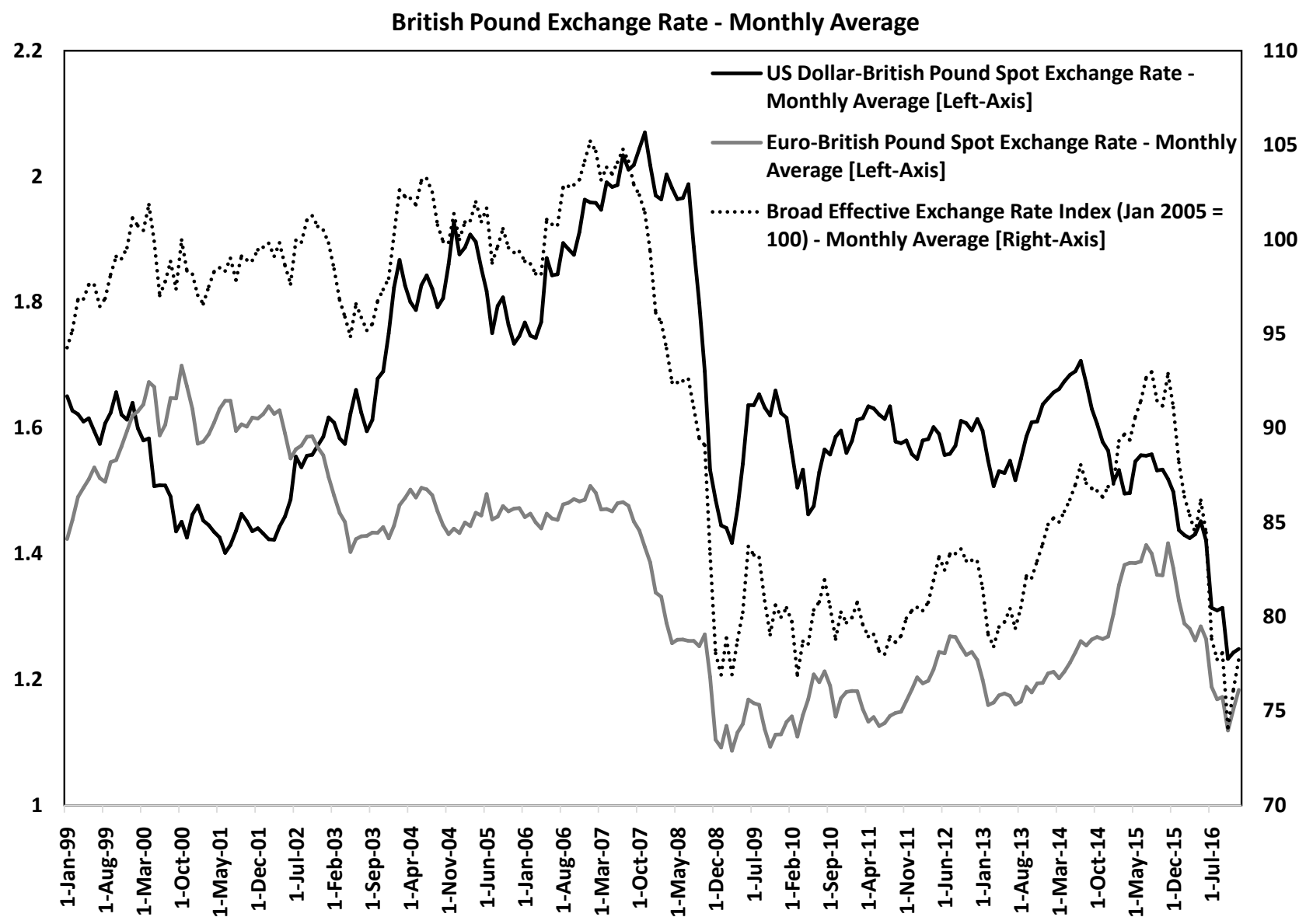

Figure 12. British pound exchange rate-monthly average (Data source: Bank of England (BOE)). 
is such that a pound depreciation against the major currencies leads to an improvement in its net foreign debt position); on the other hand, when global risks rise, safe-haven flows will typically strengthen the pound and cause a net valuation loss on the UK's international portfolio and possibly lower the investment income earned by UK residents on their overseas asset holdings [20].

It is reasonable to regard the sharp depreciation of the British pound as not only a response to the increased uncertainty about UK's future ties to the EU, but also as part of the adjustment necessary to keep the current account balance and net foreign debt at sustainable levels. The intertemporal framework discussed in the previous section indicated that current account balances would be adversely affected if trade balances and/or primary income balances were to deteriorate (see Equation (17)). Brexit is likely to negatively impact UK's service trade balance and may even hurt its goods trade balance. Additionally, UK may have to offer higher returns to foreigners due to the increase in uncertainty (and increase in risk premium), which will affect net investment income of UK residents and the primary income balance. Also, FPI and FDI flows into UK may be curtailed as foreign investors rethink their strategy of using UK as a gateway point into the European Single Market. To remain competitive and maintain its attractiveness, UK must lower its asset prices and reduce its costs. A viable avenue to achieve this is via a sharp currency depreciation. An orderly decline in the value of the British pound should therefore help UK deal with the Brexit shock. The risk, however, is that a sustained and sharp fall in the British pound would force the BOE to engage in monetary tightening, and ill-timed rate hikes may hurt underlying economic growth and spook foreign investors even more. Forced asset sales would then ensue and result in further pressure on the currency. Thus, the potential for a currency shock and financial crisis does exist.

To evaluate the impact of Brexit on UK's net international investment position, it is useful to consider both the geographical breakdown and the investment type (see Table 1). Geographically, EU (along with Norway and Switzerland) account for a considerable fraction of both UK external assets and external liabilities. As previously noted, UK net international investment position (NIIP) equals the difference between UK residents' claims on foreign assets (external assets) and overseas residents' claims on UK assets (external liabilities). The key insights from the intertemporal framework (see Equation (23) and Equation (24)) can be succinctly summarized as follows:

$$
\begin{aligned}
\Delta N I I P= & \text { Trade Balance }+ \text { Primary and Secondary Income Balance } \\
& + \text { Net Capital Gains }
\end{aligned}
$$

Net capital gains resulting from a Brexit induced depreciation of the British pound would improve UK's NIIP position. However, any deterioration of the trade balance or the primary income balance would complicate the picture and lead to a worsening of UK's net foreign debt position (more negative NIIP). From a risk standpoint, any sudden or sharp reduction in external liabilities (reduced access to the EU Single Market following Brexit, as stated earlier, could severely affect UK's ability to attract overseas investment) would force a retrenchment 
Table 1. UK international investment position-by type of investment (2014-year end data; billions of pounds); (Data source: UK Office for National Statistics (ONS)).

\begin{tabular}{|c|c|c|c|c|c|c|c|c|}
\hline \multirow{3}{*}{$\underline{\text { Regions }}$} & \multicolumn{4}{|c|}{ Assets } & \multicolumn{4}{|c|}{ Liabilities } \\
\hline & \multicolumn{4}{|c|}{ Type of Investment } & \multicolumn{4}{|c|}{ Type of Investment } \\
\hline & Direct & Portfolio & Other & $\begin{array}{c}\text { Financial } \\
\text { Derivatives }\end{array}$ & Direct & Portfolio & Other & $\begin{array}{c}\text { Financial } \\
\text { Derivatives }\end{array}$ \\
\hline $\begin{array}{c}\text { European } \\
\text { Union (EU) }\end{array}$ & 543.5 & 1082.9 & 1243.6 & 1302.4 & 593.5 & 1248.3 & 1397.3 & 1227.1 \\
\hline Norway & 4.0 & 17.8 & 17.1 & 8.1 & 6.8 & 64.5 & 22.8 & 11.5 \\
\hline Switzerland & 17.7 & 57.8 & 138.6 & 77.3 & 42.8 & 65.3 & 207.5 & 74.2 \\
\hline Total Europe & 674.2 & 1228.4 & 1549.2 & 1411.8 & 756.9 & 1448.1 & 1925.6 & 1341.6 \\
\hline Brazil & 14.9 & 36.5 & 15.4 & 3.8 & 0.2 & 0.2 & 11.6 & 3.7 \\
\hline Canada & 47.7 & 19.2 & 54.6 & 43.5 & 41.0 & 56.2 & 43.8 & 46.4 \\
\hline USA & 294.5 & 633.1 & 1027.9 & 1014.7 & 302.3 & 819.2 & 899.0 & 1063.9 \\
\hline Total Americas & 490.6 & 783.5 & 1331.3 & 1130.6 & 466.5 & 900.7 & 1206.6 & 1199.9 \\
\hline China & 8.4 & 31.2 & 28.1 & 2.7 & 2.1 & - & 65.3 & 6.8 \\
\hline Hong Kong & 55.6 & 34.8 & 58.7 & 32.0 & 16.1 & 37.3 & 66.6 & 27.4 \\
\hline India & 3.5 & 16.9 & 21.3 & 1.5 & 2.5 & - & 14.3 & 1.0 \\
\hline Japan & 6.3 & 138.6 & 260.7 & 88.4 & 42.8 & 145.6 & 135.0 & 77.7 \\
\hline Singapore & 21.7 & 15.1 & 77.1 & 26.2 & 13.5 & 26.5 & 61.4 & 20.6 \\
\hline Total Asia & 142.2 & 321.4 & 566.7 & 180.5 & 97.3 & 242.7 & 548.0 & 150.7 \\
\hline Australia & 23.6 & 59.5 & 54.0 & 83.0 & 15.2 & 34.9 & 55.9 & 87.0 \\
\hline $\begin{array}{c}\text { Total Australasia } \\
\text { and Oceania }\end{array}$ & 25.4 & 63.8 & 55.0 & 85.7 & 16.2 & 35.2 & 59.9 & 89.0 \\
\hline South Africa & 13.1 & 10.5 & 13.1 & 8.3 & 2.7 & 35.0 & 16.1 & 7.2 \\
\hline Total Africa & 51.6 & 18.3 & 38.6 & 11.3 & 12.8 & 36.4 & 73.0 & 11.6 \\
\hline $\begin{array}{l}\text { International } \\
\text { Organizations }\end{array}$ & & 31.5 & 6.5 & 8.7 & - & 52.6 & 10.8 & 13.7 \\
\hline Total & 1383.9 & 2546.9 & 3547.3 & 2828.6 & 1349.7 & 2715.7 & 3823.9 & 2806.5 \\
\hline
\end{tabular}

of UK current account deficits (which might involve financial instability and cuts to domestic expenditure). Therefore, the positive effect arising from (orderly) currency depreciation needs to be weighed against the negative effect from a potential reduction in capital flows into UK.

So far there has been no indication of any abrupt disruption in UK crossborder capital flows, but further pound depreciation or a loss of foreign investors' appetite for UK assets may occur if a "hard Brexit" (a strong break in UK-EU ties and a complete exit from the European Single Market for Britain) appears imminent. Brexit's impact will not necessarily be limited to direct and portfolio investment flows into UK, but may also affect the stock of existing investments. Unwinding of overseas investors' position in UK assets might create substantial declines in underlying asset prices which might lead to significant 
valuation effects. This will have major repercussions for UK's NIIP and current account balance.

In a 2014 speech, Deputy Governor of Bank of England Ben Broadbent stated: "... the net asset position has some bearing on the empirical relationship between the current account deficit and subsequent rates of growth. Countries with a healthier net foreign asset position are less likely to experience financial crises; they are also less prone to the precipitate reversals in current account deficits- "sudden stops" in overseas funding - that can prove very damaging for demand and economic activity" ([2], p. 4). It is typically argued that long-term capital flows, such as FDI, are safer because of their inherent "stickiness" and thus less prone to sudden reversals. A closer look at Table 1 indicates that besides FDI and FPI flows, other types of investment flows are also significant in the case of UK ("other investment" refers all other forms of investment besides FDI, FPI, financial derivatives and reserve assets; it typically consists of trade credit, loans, and currency and deposits). Given UK's role as a global and European financial center, there is a considerable amount of wholesale banking and derivatives trading intermediated via UK-based financial institutions, which are often parlayed into longer-term investments around the world (a quick glance at Figure 8 illustrates this dynamic). Historically, UK earned a positive net investment income from such activities but that appears to no longer be true. A wellregarded economics commentator summarized this evolving dynamic as follows: "In a sense, Britain is like a giant hedge fund. Its financial players borrow short and lend long on a huge scale across the world, earning a fat spread in good times. This income stream has shriveled up in our new era of secular stagnation, negative rates, and a global savings glut" [21].

To summarize, an orderly depreciation of the British pound in conjunction with a "soft Brexit" outcome (where UK retains a decent amount of access to the European Single Market system) would generally be favorable developments in the context of UK current account sustainability. In fact, such an outcome might even lead to an improvement in both UK's current account balance and net foreign debt position. However, a disorderly and sharp pound depreciation and a "hard Brexit" outcome could lead to a rapid and painful unwinding of UK current account deficits and result in significant real economic costs.

\section{Conclusions}

In recent years, UK has experienced current account deficits that are quite large by historical and international standards. There have also been sharp fluctuations in its net foreign debt levels. Current account balance, consisting of net trade, net income and net transfers, has worsened recently primarily due to a net income drain (as foreigners' investments in UK have paid off better than British investments overseas). Trade deficits, though persistent, have remained relatively stable around $2 \%$ and reflect primary a structural deficit (with EU and China) involving trade in goods. Meanwhile, currency valuation changes (and to a lesser extent asset price changes) have had a significant, and mostly favorable, impact 
on UK's net international investment position in recent years. Going forward, the momentous referendum verdict delivered by British voters will result in some form of an exit for UK from the EU. Impact of the Brexit vote on UK current account balance and net foreign debt is a major concern for international economists and British policymakers.

Standard net capital flow centric analysis of current account balances would suggest that as long as UK can attract foreign investment and run a financial account surplus, there is not much reason to worry about persistent current account deficits. However, as the careful analysis undertaken in this study indicates, there is more to the story than just a couple of simple open-economy identities. A rich intertemporal framework based analysis suggests that current account sustainability depends on multiple factors. Besides trade sector developments, primary income balances and current transfers matter directly. The return obtained on overseas asset holdings of UK residents vis-à-vis the return received by overseas investors on their UK asset holdings clearly matters. The type of investment flows used to finance the UK current account deficit also matters. Given that UK external asset holdings are typically denominated in Euros, US dollars and other foreign currencies while UK external liabilities are mostly denominated in British pounds, exchange rate changes also play a significant role in influencing current account trends.

Additionally, as the noted international macroeconomist Maurice Obstfeld observed in his 2012 Ely Lecture "large gross financial flows entail potential stability risks that may be only distantly related, if related at all, to the global configuration of saving-investment discrepancies" ([12], p. 3). Outsized external asset and external liability positions, arising from UK's role as a global financial and banking sector and London's status as the financial capital of Europe, necessitates a careful consideration of the composition of Britain's international investment position. Currency and asset price related revaluation of UK external assets and external liabilities have a massive effect on the net foreign debt position, which in turn affects the current account sustainability analysis.

The intertemporal framework detailed in this study incorporates these complexities, and therefore provides an excellent tool for evaluating the potential impact of Brexit on UK's current account balance and net international investment position. Our analysis suggests that if UK were to lose the benefits of the so-called "financial passport" rights as a result of Brexit, then London may be forced to relinquish its title as the financial capital of Europe. Consequently, UK's banking and financial sector will shrink in size in the post-Brexit era. Additionally, UK's attractiveness as a destination for direct and portfolio investment flows from both EU and non-EU regions has long depended on overseas investors' confidence in UK economic performance, and on UK's reputation as an open economy that is a global financial center and a gateway to EU. Brexit will have far-reaching effects if UK loses its access to the EU Single Market system-Britain's allure to foreign investors is to a considerable extent predicated on its status as both the financial and investment gateway into EU, and the loss 
of that position would entail a significant reduction in FDI and FPI flows into UK. Any sharp decline in capital inflows will impair UK's ability to sustain large current account deficits and potentially force significant currency depreciation and/or domestic expenditure adjustments. Additionally, the sole bright spot in UK's current account balance-persistent trade surplus in services-is dependent on London's status as a global and European financial center. Strong financial services exports have to some extent mitigated the consequences of UK's rising imports of goods, and any reduction in finance-related export of services would worsen UK's current account deficit and force an adjustment elsewhere (for instance, British ability to consume foreign made goods would be adversely affected).

The impact of the sharp depreciation of British pound in the post-referendum period (and the likelihood of sustained pound weakness in the post-Brexit era) is highlighted in this study. As long as the decline in the value of the pound is orderly and not too drastic, the currency depreciation aspect might prove to be the one silver-lining in the whole Brexit saga. Some economists have argued that the UK had long suffered from an overvalued currency and a variant of the "Dutch Disease" phenomenon - in Britain's case, it was the overreliance on finance (instead of commodities) that was responsible for economic distortions [22]. Sustained weakness in the pound will enable UK to reduce its dependence on the financial sector and lead to an improvement in its trade balance. Additionally, favorable valuation effects will help improve UK's net foreign debt position (currency composition of UK's external assets and external liabilities is such that a pound depreciation leads to an improvement in its net international investment position).

To conclude, while potential risks arising from the Brexit vote abound, the consequences for UK's current account sustainability and its net foreign debt position will depend on the answers to a couple of fundamentally important questions. First, how much access to the European Single Market can the UK preserve in any post-Brexit arrangement? Relatedly, will the EU "financial passport" rights continue to be available to London and UK based financial institutions? The answer to these questions will have enormous implications for UK's ability to attract foreign investment. Second, will any further British pound depreciation occur in an orderly manner and will the sustained weakness in the pound spook overseas investors? Moderate weakness of the pound will prove to be beneficial for UK's current account balance and net foreign debt position, but any sudden and drastic fall in the currency value would create serious complications. Clearly, "soft Brexit" and orderly and sensible downward adjustment in the value of the pound scenario is preferable to a "hard Brexit" and dramatic currency collapse scenario.

\section{References}

[1] Behr, R. (2016) How Remain Failed: The Inside Story of a Doomed Campaign. The Guardian. 
https://www.theguardian.com/politics/2016/jul/05/how-remain-failed-inside-storydoomed-campaign

[2] Broadbent, B. (2014) The UK Current Account. Speech Given at Directors Breakfast, Chatham House, London.

http://www.bankofengland.co.uk/publications/Documents/speeches/2014/speech75 $\underline{0 . p d f}$

[3] Forbes, K. (2016) The UK Current Account Deficit: Risky or Risk-Sharing? Speech given at the Official Monetary and Financial Institutions Forum, London. http://www.bankofengland.co.uk/publications/Pages/speeches/2016/890.aspx

[4] Cooper, R.N. (2007) Living with Global Imbalances. Brookings Papers on Economic Activity, 38, 91-110.

[5] Krugman, P. (2007) Will There Be a Dollar Crisis? Economic Policy, 22, 435-467. https://doi.org/10.1111/j.1468-0327.2007.00183.x

[6] Obstfeld, M. (2005) America's Deficit, the World's Problem. Monetary and Economic Studies, 23, 25-35.

[7] Caballero, R. and Arvind, K. (2009) Global Imbalances and Financial Fragility. American Economic Review, 99, 584-588. https://doi.org/10.1257/aer.99.2.584

[8] Chinn, M.D. and Hiro, I. (2007) Current Account Balances, Financial Development and Institutions: Assaying the World "Saving Glut". Journal of International Money and Finance, 26, 546-569. https://doi.org/10.1016/j.jimonfin.2007.03.006

[9] Gourinchas, P.-O. and Hélène, R. (2007) From World Banker to World Venture Capitalist: US External Adjustment and the Exorbitant Privilege. In: Clarida, R., Ed., G7 Current Account Imbalances. Sustainability and Adjustment, University of Chicago Press, Chicago. https://doi.org/10.7208/chicago/9780226107288.003.0002

[10] Borio, C. and Piti, D. (2015) Capital Flows and the Current Account: Taking Financing (More) Seriously. BIS Working Paper No. 525.

[11] Obstfeld, M. and Kenneth, R. (1996) Foundations of International Macroeconomics. MIT Press, Cambridge.

[12] Obstfeld, M. (2012) Does the Current Account Still Matter? American Economic Review, 102, 1-23. https://doi.org/10.1257/aer.102.3.1

[13] Terra, C. (2015) Principles of International Finance and Open Economy Macroeconomics. Academic Press, Waltham.

[14] Lane, P. (2015) A Financial Perspective on the UK Current Account. National Institute of Economic Review, No. 234, F67-F72. https://doi.org/10.1177/002795011523400114

[15] HM Government (2016) HM Treasury Analysis: The Immediate Economic Impact of Leaving the EU.

https://www.gov.uk/government/publications/hm-treasury-analysis-the-immediateeconomic-impact-of-leaving-the-eu

[16] Miethe, J. and Pothier, D. (2016) Brexit: What's at Stake for the Financial Sector? DIW Economic Bulletin, 6, 364-372.

[17] Bush, O., Knott, S. and Peacock, C. (2014) Why Is the UK Banking System So Big and Is That a Problem? Bank of England Quarterly Bulletin, 54, 385-395.

[18] Dhingra, S., Ottaviano, G., Sampson, T. and Van Reenen, J. (2016) The Impact of Brexit on Foreign Investment in the UK. CEP Brexit Analysis No. 3. http://cep.lse.ac.uk/pubs/download/brexit03.pdf

[19] Dhingra, S., Ottaviano, G., Sampson, T. and Van Reenen, J. (2016) The Consequences of Brexit for UK Trade and Living Standards. CEP Brexit Analysis No. 2. http://cep.lse.ac.uk/pubs/download/brexit02.pdf 
[20] Forbes, K., Hjortsoe, I. and Nenova, T. (2015) Current Account Deficits during Heightened Risk: Menacing or Mitigating? Bank of England External MPC Unit Discussion Paper No. 46.

[21] Evans-Pritchard, A. (2016) Britain Courts Fate on Brexit with Worst External Deficit in History. The Telegraph.

http://www.telegraph.co.uk/business/2016/03/31/britain-courts-fate-on-brexit-with -worst-external-deficit-in-his/

[22] Evans-Pritchard, A. (2016) Britain Should Embrace Weaker Pound and It Needs to Fall Further, Says Former BoE Governor and Currency Guru. The Telegraph. http://www.telegraph.co.uk/business/2016/10/10/currency-guru-says-pound-slide-li berates-uk-from-malign-grip-of/

\section{Scientific Research Publishing}

Submit or recommend next manuscript to SCIRP and we will provide best service for you:

Accepting pre-submission inquiries through Email, Facebook, LinkedIn, Twitter, etc. A wide selection of journals (inclusive of 9 subjects, more than 200 journals)

Providing 24-hour high-quality service

User-friendly online submission system

Fair and swift peer-review system

Efficient typesetting and proofreading procedure

Display of the result of downloads and visits, as well as the number of cited articles Maximum dissemination of your research work

Submit your manuscript at: http://papersubmission.scirp.org/

Or contact tel@scirp.org 